\title{
PROFIL DAN FAKTOR-FAKTOR YANG MEMENGARUHI EFIKASI GURU MADRASAH IBTIDAIYAH PESERTA DUAL MODE SYSTEM
}

\author{
Muna Erawati \\ Mahasiswa Program Doktor Fakultas Psikologi \\ Universitas Gadjah Mada Yogyakarta \\ munaerawati@gmail.com
}

\begin{abstract}
One of critical problem related to Islamic elementary school teacher is disadvantage teacher personality. An important aspect of teacher personality is self-efficacy. This study try to answer three questions first, bow to describe Islamic elementary school efficacy teacher profile? Secondly, what factors contribute to Islamic elementary school teacher efficacy? Thirdly, how to explain the psychological dynamic of Islamic elementary school teacher efficacy?

Teacher efficacy was defined as the teacher belief in his or her capability to organize and execute courses of actions to successfully accomplish a specific teaching task in a certain context (Tschannen-Moran, Hoy, $\mathcal{G}$ Hoy, 1998: 233). There were 132 teachers participating in this survey. They were administered Teacher Efficacy Scale which was developed by Bandura (by permission from Indigenous Psychology Team of Psychology Department of Gadjah Mada University).

Teacher efficacy score was about average level to high. Some predictors contributed significantly toward some teacher efficacy dimensions, but they did not correlate with the total score of teacher efficacy. The implication of this research will discuss later.
\end{abstract}

Keywords: Efficacy, Teacher personality, Islamic elementary school

\begin{abstract}
Abstrak
Kepribadian guru madrasab ibtidaiyah (MI) yang kurang mendukung pembelajaran masib sering dijumpai. Salab satu aspek kepribadian guru yang perlu ditinjau lebih dalam adalab efikasi guru. Studi ini hendak menjawab tiga pertanyaan — pertama, bagaimana profil efikasi guru MI peserta Program DMS (dual mode system)? Kedua, faktor-faktor apa
\end{abstract}


sajakah yang menyumbang efikasi tersebut? Ketiga, bagaimana dinamika psikologi efikasi guru MI?

Efikasi guru adalab keyakinan guru atas kapabilitasnya sendiri untuk mengorganisasi dan memutuskan langkah-langkah yang diperlukan agar berhasil memenubi suatu tugas pengajaran dan kependidikan dalam konteks tertentu (Tschannen-Moran, Hoy, E Hoy, 1998: 233). Responden yang dilibatkan 132 guru MI peserta DMS. Mereka diminta mengerjakan Skala Efikasi Guru yang dikembangkan oleb Bandura atas ijin dari Tim Psikologi Indigenos Fakultas Psikologi Universitas Gadjab Mada.

Mayoritas efikasi guru berada pada level sedang sampai tinggi. Studi ini menemukan beberapa prediktor yang terbukti signifikan memengarubi dimensi-dimensi efikasi guru, tetapi tidak ditemukan efek terhadap skor total efikasi guru. Implikasi dari studi ini akan didiskusikan lebih lanjut.

Kata kunci: Efikasi, Kepribadian guru, Madrasah Ibtidaiyah

\section{Pendahuluan}

Menurut PP No.19 Tahun 2005 tentang Standar Nasional Pendidikan Pasal 29 ayat (2), seorang guru (MI atau PAI pada sekolah) minimal harus mempunyai kualifikasi akademik sarjana (S1) atau D-IV, serta sertifikat profesi untuk guru MI atau PAI. Data perkembangan jumlah guru tahun 2006 menunjukkan bahwa guru MI dan PAI pada sekolah yang telah menyelesaikan sarjana (S1) sebanyak 220.742 orang, sementara yang masih berlatar belakang pendidikan SLTA dan D-II berjumlah 303.801 orang (Dirjen Pendidikan Islam Departemen Agama, 2009: 2).

Sesuai dengan amanat Undang-Undang, paling lama 10 tahun sejak diberlakukannya Undang-Undang tersebut, yaitu sampai 2015, semua guru harus sudah memenuhi kualifikasi akademik minimal sarjana (S1)/D-IV. Berdasar pertimbangan-pertimbangan tersebut, maka Direktorat Jenderal Pendidikan Islam Departemen Agama Republik Indonesia mulai tahun akademik 2008/2009 menyelenggarakan Program Peningkatan Kualifikasi Akademik Sarjana (S1) bagi Guru MI dan Guru PAI pada Sekolah dengan menggunakan pendekatan dual mode system (Dir. Jenderal Pendidikan Islam Departemen Agama, 2009: 3).

Selama ini beberapa kalangan masih memandang sebelah mata pada mutu madrasah. Hal ini senada dengan apa yang 
diungkapkan oleh Kepala Direktorat Pendidikan Madrasah (2008: 1-14), bahwa madrasah memiliki segudang tantangan termasuk di antaranya belum melahirkan lulusan yang berkualitas. Melalui program DMS, guru-guru MI yang belum memenuhi standar minimal kualifikasi pendidikan yaitu lulusan strata satu, mendapat kesempatan kuliah dengan bantuan biaya studi dari pemerintah. Pengalaman kuliah ini diharapkan dapat memperluas wawasan, menajamkan keterampilan, memperkokoh karakter, dan profesionalisme guru MI.

Menurut Sudarma (2007:36), dalam konteks pendidikan, guru memainkan peran kunci dalam peningkatan mutu pendidikan karena mereka berada di titik sentral pada setiap upaya reformasi pendidikan. Supriyadi dan Jalal (dalam Sudarma, 2007: 37) memaparkan empat kategori tantangan yang harus dihadapi oleh guru yaitu pengembangan karir, peningkatan kompetensi, ketrampilan psikologis, dan peningkatan kesejahteraan.

Selain faktor kualifikasi pendidikan, faktor yang menyumbang terpuruknya mutu pendidikan di Indonesia adalah faktor psikologis guru. Secara empiris, masih terlihat adanya guru-guru yang bersikap pasif dan menunggu. Sudarma (2007:37) melihat bahwa ada kecenderungan mentalitas guru yang pesimistis, fatalis, serta pragmatis. Dengan kata lain, idealisme dan daya juang guru madrasah dianggap lemah. Perasaan lemah ini disebabkan oleh rasa tidak mampu dan keengganan untuk berupaya sekuat mungkin sebagai seorang guru.

Bandura (1997:3) menyebut keyakinan akan rasa mampu tersebut sebagai efikasi (self efficacy) yaitu sebuah konstruk psikologis yang menggambarkan keyakinan seseorang atas kapabilitasnya sendiri untuk mengorganisasi dan memutuskan langkah-langkah yang diperlukan dalam mencapai tujuan tertentu. Efikasi guru berarti keyakinan diri guru atas kapabilitas untuk mengorganisasi dan memutuskan langkah-langkah yang diperlukan agar berhasil memenuhi suatu tugas pengajaran dan kependidikan dalam konteks tertentu (Tschannen-Moran et al., 1998:33). Efikasi guru yang tinggi sangat menguntungkan bagi peningkatan hasil belajar siswa (Nunn \& Jants, 2009:600), karena guru berefikasi tinggi memiliki energi psikologis yang besar untuk mencurahkan segala sumber daya dan 
potensinya bagi keberhasilan pendidikan.

Peningkatan kualitas guru, pada dasarnya mensyaratkan kualitas kepribadian guru yang dapat mencurahkan sumber daya dan potensinya bagi perkembangan anak didiknya. Keprihatinan yang mendalam akan karakteristik psikologis guru madrasah yang dengan sedemikian tersebut, dan mengingat betapa pentingnya peran efikasi dalam profesi keguruan, maka perlu dilakukan dilakukan studi tentang efikasi pada guru-guru madrasah ibtidaiyah.

Adapun rumusan masalah yang hendak diajukan - pertama, bagaimana profil efikasi guru madrasah peserta Program DMS di lokasi penelitian? Kedua, faktor-faktor apa sajakah yang menyumbang profil efikasi guru madrasah tersebut? Ketiga, bagaimana dinamika psikologi efikasi guru madrasah? Studi ini bermaksud untuk mendeskripsikan profil efikasi guru madrasah peserta Program DMS dan faktor-faktor yang menyebabkan tinggi atau rendahnya efikasi guru madrasah tersebut.

\section{Efikasi Guru dan Prediktornya}

Berdasarkan telaah yang dilakukan Tschannen-Moran et al. (1998:1-2) studi tentang efikasi yang pertama kali di dunia dilakukan oleh organisasi RAND yang menggunakan Teori Rotter tentang social learning theory pada tahun 1976.

Berdasarkan Kamus Inggris Indonesia (Echols \& Shadily, 1996:207) efikasi secara harfiah bermakna kemanjuran atau kemujaraban. Efikasi oleh Bandura (1997: 2-5) dianggap sebagai dasar dari perilaku manusia, sebab maknanya adalah keyakinan pada kapabilitas seseorang untuk mengorganisasikan dan memutuskan serangkaian perilaku yang dibutuhkan untuk mencapai tujuan tertentu. Kunci tindakan bertujuan adalah seberapa kuat keyakinan untuk terus berusaha tanpa mempedulikan apakah hasilnya positif atau negatif. Definisi efikasi gurui yang dikemukakan Campbell (1996:5) yaitu keyakinan guru bahwa ia dapat melakukan tindakantindakan tertentu untuk memengaruhi hasil belajar siswa.

Sesuai dengan permasalahan kepribadian guru MI di kancah penelitian dan tujuan pendidikan nasional, maka pengertian efikasi merujuk pada konsep Tschannen-Moran et al. (1998: 233) yaitu 
keyakinan diri guru atas kapabilitas untuk mengorganisasi dan memutuskan langkah-langkah yang diperlukan agar berhasil memenuhi suatu tugas pengajaran dan kependidikan dalam konteks tertentu.

Bila empat kompetensi guru yang tercantum dalam Undangundang Republik Indonesia No 14 tahun 2005 tentang Guru dan Dosen, dikaitkan dengan teori Bandura (dalam Tschannen-Moran et al., 1998:219) mengenai tujuh dimensi efikasi, maka diperoleh empat pengelompokkan. Pertama, efikasi dalam mengajar (instructional self-efficacy) mengungkap kompetensi paedagogik. Kedua, efikasi dalam pendisiplinan kelas (disciplinary self-efficacy) dipakai mengungkap kompetensi kepribadian. Ketiga, efikasi memengaruhi pembuatan keputusan (efficacy to influence decision making), efikasi memengaruhi sumber daya sekolah (efficacy to influence school resources), efikasi melibatkan orang tua (efficacy to enlist parental involvement), dan efikasi melibatkan komunitas (efficacy to enlist community involvement) sejalan dengan kompetensi sosial. Keempat, efikasi menciptakan iklim positif sekolah (efficacy to create a positive school climate) sejalan dengan kompetensi profesional.

Sumber-sumber efikasi meliputi pengalaman menguasai suatu kompetensi (enactive mastery experiences), pengalaman melihat konsekuensi yang terjadi pada orang lain (vicarious experiences), persuasi verbal (verbal persuasion), dan kondisi fisiologis dan afektif (Bandura, 1997:79-115).

Beberapa studi terdahulu melaporkan bahwa efikasi guru berkaitan dengan beberapa variabel demografi yaitu etnis (Cakiroglu, Cakiroglu, \& Boone, 2005: 36), lokasi tempat tinggal (Cheung, 2008: 115), jenis kelamin (Cheung, 2008: 115), usia (Houkamau \& Sibley, 2010:1-21; Lee \& Tsai, 2010:15-19), tipe institusi (Milson \& Mehlig, 2002:51; Chang, McKeachie, \& Lie, 2010:214), dan status sosial ekonomi (Ross \& Gray, 2006:807). Dalam riset di atas, yang berkarakteristik laki-laki, berusia lebih matang, bekerja pada institusi swasta berafiliasi religi atau negeri, dan berstatus ekonomi mapan ditemukan lebih efikasius daripada guru yang berusia lebih muda, perempuan, bekerja pada instansi swasta, dan berstatus sosial ekonomi rendah.

Sedangkan sejumlah riset tidak menjumpai keterkaitan antara efikasi guru dengan jenis kelamin (Cakiroglu et al., 2005: 36; Huang 
\& Liu, 2007:710; Houkamau \& Sibley, 2010:11), usia (Milson \& Mehlig, 2002:51; Houkamau \& Sibley, 2010:11), kualifikasi pendidikan (Milson \& Mehlig, 2002:51), dan jenjang pendidikan yang diajar (Milson \& Mehlig, 2002:51). Hal ini mengindikasikan bahwa masih terdapat kontradiksi mengenai temuan dari pengaruh variabel demografi terhadap efikasi guru.

Efikasi guru terbukti berkorelasi dengan faktor-faktor pengalaman instruksional yaitu pengalaman mengajar atau lama mengajar (Campbell et al., 1996:7; Huang \& Liu, 2007:710; Lee \& Tsau, 2010:15-19), dan sikap keterbukaan dan pengalaman menguasai inovasi pembelajaran dan teknologi (Wertheim \& Leyser, 2002:5463; Jennett, Harris, \& Mesibor, 2003:589). Guru yang lebih lama mengajar, lebih terbuka dengan perkembangan inovasi pembelajaran dan teknologi dijumpai lebih efikasius. Sementara itu, studistudi yang lain tidak menemukan keterkaitan efikasi guru dengan keluasan wawasan (Ross \& Gray, 2006:807), dan pengalaman mengajar (Milson \& Mehlig, 2002:51).

Faktor-faktor personal yang memengaruhi efikasi guru diketahui spiritualitas dan konsep diri interdependensi (Houkamau \& Sibley, 2010:1-21), komitmen pada profesi (Jennett et al., 2003:589), dan harga diri (Huang \& Liu, 2007: 710) Jennett et al. (2003:589) justru tidak menemukan faktor-faktor personal terhadap efikasi guru yaitu kelelahan emosi, depersonalisasi, dan pencapaian cita-cita. Pendidik yang berkarakteristik positif diprediksikan lebih efikasius.

Berdasarkan teori efikasi dari Bandura (1997:79-115) dan temuan yang relevan dengan faktor-faktor yang memengaruhi efikasi guru, maka diperoleh tiga kelompok faktor yang berefek yaitu faktor demografi, pengalaman instruksional, dan personal. Penelitian mengenai peran persuasi verbal dan pengalaman vikarius terhadap efikasi guru jarang diketemukan, sebagian besar studi menguji efek variabel demografi. Penelitian ini akan berfokus pada sembilan variabel yang terdiri dari tiga variabel demografi yaitu usia, status sosial ekonomi, dan lama mengajar. Ada enam variabel yang mengukur etnisitas, religiusitas, persepsi (kompetensi mengajar, kesejahteraan guru, dan sertifikasi guru), serta indeks prestasi. 
Kondisi-kondisi yang menguntungkan dalam faktor demografi, memiliki pengalaman instruksional yang beragam, dan kualitas afektif yang positif akan meningkatkan efikasi guru. Sebaliknya, guru yang skornya lebih rendah dalam aspek status sosial ekonomi, usia, pengalaman, religiusitas, etnisitas, persepsi terhadap kompetensi, persepsi terhadap kesejahteraan, persepsi terhadap sertifikasi guru, dan indeks prestasinya, maka cenderung kurang efikasius dalam menjalankan tugas.

\section{Metode Penelitian}

Penelitian ini merupakan studi deskriptif kuantitatif yang bersifat eksploratif. Lokasi penelitian adalah di sebuah PTAIN (Perguruan Tinggi Agama Islam Negeri) di Jawa Tengah. Perguruan tinggi agama ini menjadi LPTK mitra penyelenggara program DMS yang ditunjuk Kementerian Agama RI.

Subjek penelitian ini adalah guru-guru MI peserta Program Dual Mode System (DMS). Mahasiswa Program DMS yang berada di kancah penelitian berjumlah 301 orang. Mereka dikelompokkan menjadi beberapa kelas berdasarkan pendidikan terakhir yang dimiliki yaitu lulusan SLTA atau sederajat GPAI (Guru Pendidikan Agama Islam), lulusan D2 (Diploma Dua) linier GPAI, lulusan D2 tidak linier GPAI, lulusan SLTA atau sederajat PGMI (Pendidikan Guru Madrasah Ibtidaiyah), lulusan D2 linier PGMI, dan lulusan D2 tidak linier PGMI.

Teknik sampling yang digunakan adalah purposive technique sampling, di mana partisipan yang mengumpulkan skala sebanyak 183 orang. Ketika dilakukan pengelompokkan kelas, ternyata skala saling tercampur, sehingga peneliti kesulitan dalam mengidentifikasi pendidikan terakhir subjek. Akhirnya, setelah melalui proses penyortiran diperoleh 132 responden berstatus guru MI. Sebelum pengisian skala, diadministrasikan terlebih dulu biodata responden

Skala Efikasi Guru yang dikembangkan Bandura setelah diijinkan oleh Tim Psikologi Indigenos Fakultas Psikologi Universitas Gadjah Mada Yogyakarta digunakan untuk mengungkap efikasi guru. Skala Efikasi Guru tersebut berisi 30 aitem dengan Skala Likert dengan poin 1 sampai 9 di mana semakin besar angka 
menunjukkan semakin besar efikasi guru. Subjek dipandu oleh sebuah pernyataan yang tidak selesai yaitu, "Seberapa besar usaha Bapak/Ibu dalam hal.....". Aitem-aitem pernyataan di bawahnya merupakan kelanjutannya. Tugas subjek memberi tanda (") pada kolom-kolom yang disediakan sesuai dengan laporan subjek. Contoh aitemnya, "memengaruhi keputusan yang dibuat sekolah." Skala ini mengungkap efikasi guru dalam beberapa aspek pendidikan yaitu efikasi dalam memengaruhi pengambilan keputusan, pengadaan sumber daya sekolah, intruksional, pendiplinan, pelibatan orangtua, pelibatan masyarakat, dan penciptaan iklim positif sekolah. Berdasarkan pendapat Nunnally (dalam Ghozali, 2001:132-134), suatu konstruk atau variabel dikatakan reliabel jika memberikan nilai Cronbach Alpha lebih besar dari 0,6 (á >0,6). Setelah dihitung, 30 aitem dengan 85 subjek diperoleh koefisien reliabilitas sebesar 0,93. Dengan demikian maka, Skala Efikasi Diri Guru yang disusun Bandura ini memiliki reliabilitas yang tinggi.

Selain skala efikasi guru, ada beberapa pertanyaan yang mewakili sembilan prediktor. Skala Likert yang digunakan pada instrumen bergerak dari 0 sampai 4 . yang meliputi: pertama, mengungkap sejauhmana subjek mengidentifikasi diri dengan agama. Subjek disodori pertanyaan,"Seberapa kuatkan Anda mengidentifikasikan diri dengan agama Anda?" Respon disediakan berbentuk skala Likert lima poin dari sangat kuat sampai sangat tidak kuat. Kedua, mengungkap sejauhmana subjek mengidentifikasi diri dengan etnis. Subjek disodori pertanyaan,"Seberapa kuatkan Anda mengidentifikasikan diri dengan kelompok kultur atau etnis Anda? Pilihlah salah satu". Respon disediakan berbentuk skala Likert lima poin dari sangat kuat sampai sangat tidak kuat.

Ketiga, mengungkap laporan subjek pada kompetensi dirinya sebagai guru. Subjek disodori pertanyaan,"Menurut anda, kemampuan (kompetensi) diri Anda sebagai guru:...". Respon disediakan berbentuk skala Likert lima poin dari sangat kompeten sampai sangat tidak kompeten. Keempat, mengungkap lama menjadi guru. Subjek diminta menuliskan jumlah tahun dan bulan lamanya menjadi guru. Kelima, mengungkap status sosial ekonomi. Subjek diminta menjawab pertanyaan,"Bagaimanakah standar kehidupan keluarga Anda?" Respon disediakan berbentuk skala Likert lima poin dari 
sangat kaya sampai rendah. Keenam, mengungkap penilaian terhadap tingkat kesejahteraan guru. Subjek disodori pertanyaan," Menurut anda, kesejahteraan guru saat ini:..." "Respon disediakan berbentuk skala Likert lima poin dari sangat sejahtera sampai sangat tidak sejahtera. Ketujuh, mengungkap persepsi dampak sertifikasi pada kinerja guru. Subjek disodori pertanyaan,"Menurut anda, apakah sertifikasi guru dapat meningkatkan kinerja guru?" Respon disediakan berbentuk skala Likert lima poin dari sangat yakin sampai sangat tidak yakin. Kedelapan, mengungkap umur. Subjek diminta mencantumkan usianya. Kesembilan, mengungkap indeks prestasi kumulatif. Subjek diminta menuliskan IPK yang terakhir.

Mengingat penelitian ini merupakan penelitian kuantitatif deskriptif, maka digunakan piranti statistik sebagai alat analisis. Program SPSS 16 (Statistic for Social Sciences) digunakan untuk mempermudah penghitungan sesuai dengan panduan Field (2000: 33 -162). Ada beberapa tahap dalam analisis data: pertama, data ditabulasi. Kedua, data dianalisis dengan beberapa teknik yaitu a) statistik deskriptif untuk menemukan skor minimum, skor maksimal, rerata, standar deviasi, dan skewness untuk melihat apakah data berdistribusi normal atau tidak. b) Histogram digunakan untuk menampilkan profil setiap data. c) Crosstab untuk menemukan persentase dan frekuensi. d) Uji independent sample T test untuk melihat perbedaan rerata dua kelompok. e) Uji korelasional untuk melihat keterkaitan antara dua variabel. f) Uji regresi linear untuk melihat koefisien determinasi sebagai tolok ukur seberapa jauh suatu model menerangkan variasi dari variabel dependen.

\section{Pembahasan}

Identifikasi guru madrasah terhadap agamanya sebagian besar kuat $(47,7 \%)$, tetapi masih ada guru yang merasa lemah $(3,7 \%)$ dan sangat lemah (0,8\%). Menariknya, meskipun bekerja dalam institusi pendidikan keagamaan dan sebagian besar berlatar belakang pendidikan agama, kondisi ini tidak lantas membuat mereka mengidentifikasi pada agama secara totalitas. Hal ini terlihat dari hanya 11,4\% yang menyatakan sangat kuat. Sebanyak 31,1\% merasa cukup kuat. 
Semua subjek beretnis Jawa. Berbeda dengan religiusitasnya yang kuat, para guru umumnya merasa hanya cukup kuat dalam mengidentifikasi etnis. Hal ini menunjukkan bahwa para guru madrasah bukan termasuk kelompok yang sangat "njawani" atau kental dengan nilai-nilai budaya Jawa. Sebaliknya mereka lebih cenderung merujuk pada agama.

Penilaian diri terhadap kompetensi mengajar dilaporkan cukup oleh 63,65\% responden. Ada 18,94\% yang merasa sangat kompeten. Mereka ini umumnya guru dengan masa mengajar yang sudah lama. Sementara itu, sebagian besar yaitu 41,66\% subjek memiliki pengalaman awal sebagai guru yakni 1 sampai 6 tahun. Sementara itu, umur terbanyak berkisar 20-33 tahun yaitu sebanyak 56\%. Dengan usia masih muda dan jam terbang mengajar terbatas, maka kemungkinan besar mereka merasa kompetensi mengajarnya masih pada taraf cukup.

Latar belakang sosial ekonomi guru madrasah hampir seluruhnya berasal dari keluarga sederhana. Hal ini tersimpul dari 84,86\% guru melaporkan kondisi sosial ekonomi keluarganya cukup. Sebagian lagi berasal dari keluarga dengan ekonomi lemah $(11,36 \%)$ dan sangat lemah (3,03\%). Sementara itu, hanya 0,75\% yang mengaku dari keluarga kaya. Tidak ada subjek yang melaporkan dari keluarga sangat kaya. Laporan ini sesuai dengan latar belakang keluarga asal subjek yang mayoritas petani, pedagang kecil, maupun buruh.

Penilaian terhadap kesejahteraan guru saat ini cukup berimbang antara cukup (29,54\%), layak (28,79\%), dan tidak layak (25,76\%). Sebanyak 11,36\% menganggap sangat tidak layak, namun ada 4,55\% menilai sangat layak. Ketika dicek, jawaban kelompok sangat layak ini, tidak terkait dengan status kepegawaiannya. Ada satu orang berstatus PNS, lima lainnya berstatus non PNS. Kondisi ini mengindikasikan adanya sikap menerima apa adanya penghasilan dari profesi mengajarnya tersebut, walaupun sebagian guru yang lain sudah menggugat adanya ketidak layakan kompensasi untuk guru madrasah. Ketika ditanyakan tentang pengaruh program sertifikasi pada kinerja guru, 38,64\% menjawab yakin berpengaruh. Hal ini menunjukkan bahwa meskipun mereka bersikap menerima apa adanya penghasilan yang belum layak untuk guru wiyata, tetapi 
mereka masih berharap agar sertifikasi guru mengubah kondisi mereka.

Prestasi belajar mereka selama di bangku kuliah program beasiswa DMS menunjukkan hasil yang menggembirakan. Sebanyak $32,58 \%$ berindeks prestasi sangat baik, istimewa (24,25\%), baik (23,48\%), cukup (14,39\%), dan kurang (5,3\%). Meskipun kategorinya kurang, tetapi sesungguhnya interval IPK berkisar 2,52,75 dengan skala 0 sampai 4. Interval ini mengindikasikan bahwa prestasi belajar para guru peserta program beasiswa DMS cukup membanggakan. Keberadaan guru dalam program DMS ini nampaknya juga membawa pengaruh positif berupa semangat untuk belajar. Berdasarkan ungkapan beberapa peserta, mereka umumnya amat senang lolos seleksi peserta beasiswa DMS, sebab sudah sejak lama mereka memimpikan bisa melanjutkan kuliah S1. Faktor ekonomi adalah kendala yang menghambat keinginan tersebut. Dengan adanya program beasiswa DMS tersebut, mereka merasa mendapat kesempatan yang selama ini ditunggu-tunggu. Kondisi inilah yang menjelaskan mengapa semangat belajar mereka masih cukup baik dan menghasilkan prestasi yang tidak mengecewakan.

Berdasarkan penghitungan dengan teknik statistik deskriptif, diperoleh rangkuman hasil sebagai berikut:

\section{Tabel 1}

\section{Rangkuman Data Indikator Efikasi Diri Guru Total}

\begin{tabular}{cccccc}
\hline F & $\begin{array}{c}\text { Skor } \\
\text { Min }\end{array}$ & Skor Maks & $\begin{array}{c}\text { Rerata } \\
\text { (Mean) }\end{array}$ & SD & Skewness \\
\hline Ef1 & 2 & 18 & 12,64 & 2,68 & $-0,72$ \\
Ef2 & 1 & 9 & 5,81 & 2,16 & $-0,67$ \\
Ef3 & 35 & 86 & 63,84 & 7,9 & $-0,27$ \\
Ef4 & 13 & 27 & 22,91 & 2,95 & $-0,62$ \\
Ef5 & 10 & 27 & 20,49 & 3,8 & $-0,35$ \\
Ef6 & 4 & 35 & 21,92 & 6,77 & $-0,17$ \\
Ef7 & 29 & 76 & 59,37 & 9,25 & $-0,5$ \\
Ef Tot & 126 & 258 & 207,63 & 27,04 & $-0,266$ \\
\hline
\end{tabular}

Keterangan:

Skor min= skor minimal; skor maks=skor maksimal; SD=standar deviasi; efikasi pengambilan keputusan sekolah (Ef1), efikasi dalam pengadaan sumber daya (Ef2), efikasi dalam instruksional (Ef3), efikasi dalam pendisiplinan (Ef4), efikasi dalam pelibatan orangtua murid (Ef5), efikasi dalam pelibatan masyarakat (Ef6), efikasi dalam penciptaan iklim positif di sekolah (Ef7), dan efikasi total (Ef Tot). 
Skor total efikasi guru diperoleh dari akumulasi tujuh dimensi efikasi guru. Bila dicermati, histogram berdistribusi normal dengan skewness $(-0,266)$. Berdasarkan tabel perbandingan skor hipotetik dan empirik efikasi guru maka, diketahui rerata menunjukkan angka 207,63 artinya rerata perolehan subjek di atas rerata hipotetiknya.

Tabel 2

Perbandingan Skor Hipotetik dengan Empirik

\begin{tabular}{cccccc}
\hline \multicolumn{2}{c}{ Skor Hipotetik } & \multicolumn{2}{c}{ Skor Empirik } & \multicolumn{2}{c}{ Mean } \\
\hline Skor & Skor & Skor & Skor & Hipoteti & \multirow{2}{*}{ Empirik } \\
Min & Maks & Min & Maks & k & \\
30 & 270 & 126 & 258 & 150 & 207,63 \\
\hline
\end{tabular}

Untuk menentukan posisi masing-masing subjek maka dihitung distribusi frekuensi, persentase, dan kelasnya. Berdasarkan tabel di bawah, dapat diketahui bahwa guru madrasah memiliki tingkat efikasi guru sedang (39,4\%), tinggi (32,6\%), rendah $(16,7 \%)$, sangat tinggi $(9,1 \%)$, dan sangat rendah $(2,2 \%)$.

\section{Tabel 3}

\section{Frekuensi dan Kelas Efikasi Diri Guru}

\begin{tabular}{cccl}
\hline Interval & Frek & $\begin{array}{c}\text { Persentase } \\
(\%)\end{array}$ & \multicolumn{1}{c}{ Kelas } \\
\hline $125-155$ & 3 & 2,2 & Sangat Rendah \\
$156-185$ & 22 & 16,7 & Rendah \\
$186-215$ & 52 & 39,4 & Sedang \\
$216-245$ & 43 & 32,6 & Tinggi \\
$246-275$ & 12 & 9,1 & Sangat Tinggi \\
\hline
\end{tabular}

Data Ef1 berdistribusi normal dengan skewness $(-0,72)$ sementara reratanya adalah $(12,64)$ dengan standar deviasi $(2,68)$.

Tabel 4

Frekuensi dan Kelas Ef1

\begin{tabular}{cccc}
\hline Interval & Frek & Persentase $\%$ & Kls \\
\hline $1-6$ & 4 & 3,03 & Rendah \\
$7-12$ & 55 & 41,67 & Sedang \\
$13-19$ & 73 & 55,3 & Tinggi \\
\hline
\end{tabular}


Bila data dikelompokkan dalam tiga kategori, maka mayoritas guru MI memiliki efikasi tinggi dalam aspek memengaruhi pengambilan keputusan $(55,3 \%)$. Sebagian subjek yang lain berada pada level sedang $(41,67 \%)$ dan rendah $(3,03 \%)$.

Histogram Ef2 memperlihatkan bahwa data berdistribusi normal dengan skewness $(-0,67)$ sementara rerata adalah $(5,81)$ dengan standar deviasi 2,16.

Tabel 5

Frekuensi dan Kelas Skor Ef2

\begin{tabular}{cccl}
\hline Interval & Frek & $\begin{array}{c}\text { Persentase } \\
\%\end{array}$ & Kelas \\
\hline $1-3$ & 23 & 17,42 & Rendah \\
$4-6$ & 50 & 37,88 & Sedang \\
$7-10$ & 59 & 44,7 & Tinggi \\
\hline
\end{tabular}

Tabel di atas menunjukkan adanya jumlah subjek yang berada pada kategori tinggi (44,7\%), sedang (37,88\%), dan rendah $(17,42)$. Artinya sebagian besar guru memiliki efikasi tinggi dalam memengaruhi pengadaan sumber daya sekolah.

Tabel 6

Frekuensi dan Kelas Skor Ef3

\begin{tabular}{cccl}
\hline Interval & Frek & Persentase \% & \multicolumn{1}{c}{ Kelas } \\
\hline $35-46$ & 2 & 1,5 & Sangat Rendah \\
$47-56$ & 16 & 12,1 & Rendah \\
$57-66$ & 60 & 45,45 & Sedang \\
$67-76$ & 46 & 34,85 & Tinggi \\
$77-86$ & 8 & 6,1 & Sangat Tinggi \\
\hline
\end{tabular}

Grafik histogram menunjukkan bahwa data Ef3 berdistribusi normal dengan skewness $(-0,27)$ dan rerata $(63,84)$ dan standar deviasi $(7,9)$. Tabel di atas menginformasikan sebanyak 45,45\% guru memiliki efikasi instruksional pada level sedang, 34,85\% pada level tinggi, 12,1\% pada level rendah, 6,1\% pada level sangat tinggi, dan level sangat rendah $1,5 \%$. 


\section{Tabel 7}

\section{Frekuensi dan Kelas Skor Ef4}

\begin{tabular}{cccl}
\hline Interval & Frek & Prosentase $\%$ & Kelas \\
\hline $12-16$ & 4 & 3,1 & Rendah \\
$17-22$ & 53 & 40,1 & Sedang \\
$23-28$ & 75 & 56,8 & Tinggi \\
\hline
\end{tabular}

Grafik histogram menunjukkan bahwa data Ef 4 berdistribusi normal dengan skewness $(-0,62)$ dan rerata $(22,91)$ dengan standar deviasi $(2,95)$. Data efikasi dalam aspek pendisiplinan menunjukkan bahwa para guru sebagian besar berada pada level tinggi $(56,8 \%)$, sedang $(40,1)$, dan rendah $(3,1 \%)$.

Grafik histogram menunjukkan bahwa data Ef5 berdistribusi normal dengan skewness $(-0,35)$ dan rerata $(20,49)$ dengan standar deviasi $(3,8)$.

Tabel 8

Frekuensi dan Kelas Skor Efikasi Pelibatan Orangtua (Ef5)

\begin{tabular}{cccc}
\hline Interval & Frekuensi & Prosentase $\%$ & Kelas \\
\hline $10-16$ & 19 & 14,4 & Rendah \\
$17-23$ & 87 & 65,9 & Sedang \\
$24-30$ & 26 & 19,7 & Tinggi \\
\hline
\end{tabular}

Guru sebagian besar berada pada level sedang (65,9\%), tinggi $(19,7 \%)$, dan rendah $(14,4 \%)$ dalam pelibatan orangtua murid.

Tabel 9

Frekuensi dan Kelas Skor Ef6

\begin{tabular}{cccc}
\hline Interval & Frek & Prosentase $\%$ & Kelas \\
\hline $4-15$ & 16 & 12,12 & Rendah \\
$16-25$ & 104 & 78,78 & Sedang \\
$26-35$ & 12 & 9 & Tinggi \\
\hline
\end{tabular}

Grafik histogram menunjukkan bahwa data Ef6 berdistribusi normal dengan skewness $(-0,17)$ dan rerata $(21,92)$ dengan standar deviasi $(6,77)$.

Guru MI mayoritas beranggapan bahwa efikasinya dalam melibatkan partisipasi masyarakat berada pada level sedang 
(78,78\%). Sementara itu, 12,2\% merasa tidak efikasius dalam pelibatan masyarakat, dan hanya 9\% yang merasa yakin dalam mengusahakan keterlibatan masyarakat.

\section{Tabel 10}

\section{Frekuensi dan Kelas Skor Ef7}

\begin{tabular}{cccl}
\hline Interval & Frek & Prosentase $\%$ & \multicolumn{1}{c}{ Kelas } \\
\hline $29-38$ & 2 & 1,5 & Sangat Rendah \\
$39-48$ & 16 & 12,12 & Rendah \\
$49-58$ & 43 & 32,58 & Sedang \\
$59-68$ & 48 & 36,36 & Tinggi \\
$69-78$ & 23 & 17,42 & Sangat Tinggi \\
\hline
\end{tabular}

Grafik histogram menunjukkan bahwa data Ef7 berdistribusi normal dengan skewness $(-0,5)$ dan rerata $(59,36)$ dengan standar deviasi $(9,25)$. Berdasarkan tabel di bawah, terlihat bahwa guru MI melaporkan tingkat efikasi penciptaan iklim positif di sekolah 36,36\% tinggi, 32,58\% sedang, sangat tinggi 17,42\%, rendah, 12,12\%, dan $1,5 \%$ sangat rendah.

Paparan data deskriptif menunjukkan bahwa efikasi guru total yang dimiliki subjek tergolong sedang dan tinggi baik secara total maupun pada masing-masing indikator. Temuan ini mematahkan dugaan bahwa efikasi guru madrasah cenderung rendah. Walaupun sebagian besar subjek memiliki pengalaman menjadi guru bersifat masih awal dan usia cukup muda, tetapi mereka memiliki keyakinan yang cenderung tinggi pada pengaruh diri pada aspek-aspek pendidikan.

Hasil penelitian memperlihatkan dua kelompok yaitu pertama, persentase terbanyak pada kategori tinggi. Indikator yang termasuk dalam kelompok ini adalah efikasi dalam pengambilan keputusan sekolah (Ef1), efikasi dalam pengadaan sumber daya (Ef2), efikasi dalam pendisiplinan (Ef4), dan efikasi dalam penciptaan iklim positif di sekolah (Ef7). Kelompok dua, persentase terbanyak pada kelompok sedang. Yang termasuk dalam kelompok ini adalah efikasi dalam instruksional (Ef3), efikasi dalam pelibatan orangtua murid (Ef5), dan efikasi dalam pelibatan masyarakat (Ef6).

Hasil ini memberitahukan bahwa guru MI memiliki kekuatan yang tinggi dalam memengaruhi keputusan. Iklim demokratis 
nampaknya memiliki pengaruh kuat pada persamaan hak berpendapat di madrasah. Hal inilah yang mendorong para guru berani untuk mengungkapkan pendapat dan ikut berperan dalam memengaruhi pengambilan keputusan. Sinyalemen positif ini menunjukkan bahwa meskipun mayoritas berstatus swasta, guru-guru merasa memiliki peran signifikan dalam pengelolaan madrasah.

Sejarah kelahiran madrasah di Indonesia berakar dari aspirasi masyarakat, dikelola serta didanai oleh masyarakat, dan diperuntukkan oleh masyarakat. Hal ini memperlihatkan bahwa nilai demokratis sejak awal sudah diejawantahkan di madrasah. Mayoritas MI di Indonesia yang berstatus swasta, mempertegas praktek gotong royong dan musyawarah dalam pengelolaan madrasah. Rosyada (2004:1-15) menyebutkan bahwa atmosfer demokratis teramat penting bagi terciptanya partisipasi kolektif di sekolah.

Hasil uji beda dengan teknik independent-samples T test menunjukkan bahwa terdapat perbedaan signifikan Ef1 dilihat dari status kepegawaian $(\mathrm{F}=4,5 ; \mathrm{p}=0,036)$, dan $\mathrm{Ef} 5$ dilihat dari kelompok usia $(\mathrm{F}=4,081 ; \mathrm{p}=0,045)$. Hal ini menunjukkan bahwa guru yang berstatus belum PNS lebih efikasius dalam pengambilan keputusan sekolah, dan guru yang memiliki pengalaman mengajar lebih banyak cenderung lebih efikasius dalam pelibatan orang tua.

Efikasi guru dalam memengaruhi keputusan sekolah (Ef1) berbeda signifikan antara guru berstatus PNS dan non PNS, di mana justru kelompok non PNS lebih efikasius dibanding kelompok PNS. Mayoritas guru MI dalam studi ini berstatus non PNS, dan hal ini mencerminkan kondisi guru MI keseluruhan. Temuan ini cukup menarik. Ada dua penjelasan yang membantu memahami temuan tersebut. Pertama, bila dibandingkan kelompok guru madrasah berstatus PNS dengan non PNS dari segi usia serta pengalaman mengajar, ditemui bahwa kelompok non PNS berusia dan memiliki pengalaman yang lebih banyak dibanding guru PNS. Usia dan pengalaman yang lebih matang inilah yang memungkinkan guru non PNS lebih merasa berpengaruh dalam pembuatan keputusan di madrasah.

Kedua, perbedaan perilaku interpersonal yang ditunjukkan guru non PNS di madrasah. Ada kemungkinan para guru non PNS memiliki hubungan interpersonal yang kondusif dengan siswa dan 
sesama guru. Hubungan interpersonal yang kuat ini, khususnya dengan kolega memungkinkannya memengaruhi keputusan di sekolah. Kondisi ini sesuai studi Van Petegem et al. (2005:34-43) yang menemukan bahwa guru berstatus pekerjaan belum jelas, sudah berkeluarga, dan memiliki anak cenderung lebih suka menolong dan ramah dibanding koleganya yang berstatus jelas.

Hasil uji korelasi bivariat menunjukkan bahwa status sosial ekonomi berkorelasi dengan Ef2 ( $\left.r=-0,176^{*} ; \mathrm{p}=0,044\right)$, Ef4 dengan religiusitas $\left(r=0,171^{*} ; \mathrm{p}=0,049\right)$, dan Ef6 dengan lama mengajar sebesar $\left(r=0,227^{* *} ; \mathrm{p}=0,009\right)$. Hasil ini memperlihatkan bahwa semakin mapan status sosial ekonomi, guru akan semakin efikasius dalam mempengaruhi sumber daya di sekolah. Semakin religius, guru akan semakin efikasius dalam pendisiplinan di kelas. Semakin guru memiliki pengalaman mengajar yang lama, maka semakin efikasius dalam pelibatan masyarakat.

Faktor yang memengaruhi tinggi rendahnya efikasi guru dalam pengadaan sumber daya sekolah adalah status sosial ekonomi. Sementara itu, status sosial ekonomi guru memperlihatkan bahwa mayoritas mengaku berstatus cukup, penilaian pada kesejahteraan sebagai guru juga umumnya merasa cukup. Dengan status sosial ekonomi dan penilaian pada kesejahteraan cukup layak inilah maka efikasi guru secara total menunjukkan sedang, kemudian efikasi pengadaan sumber daya skornya tinggi. Menariknya, meskipun mayoritas berstatus belum PNS — dengan gaji yang belum bisa dikatakan layak — tetapi guru MI bersikap positif.

Studi ini juga menemukan adanya indikasi bahwa guru madrasah efikasius dalam mendisiplinkan murid (Ef4). Bila ditilik dari usia siswa, maka pendisiplinan memang dipandang sebagai pendekatan yang sesuai level perkembangan psikologi siswa madrasah. Hal ini membuat keyakinan para responden yang tinggi pada usaha-usaha pendisiplinan. Pendisiplinan menurut Slavin (2012: 315351) adalah suatu metode yang digunakan untuk mencegah, merespon, dan mengurangi kemungkinan perilaku yang tidak diharapkan terjadi di waktu mendatang. Menurut Van Petegem et al. (2005:3443) pendisiplinan juga bisa dimaknai sebagai strategi yang digunakan untuk mengendalikan siswa dalam batas-batas tertentu agar kegiatan belajar dan mengajar dapat berjalan dengan lancar. 
Hasil uji korelasi menunjukkan ada keterkaitan antara religiusitas dengan efikasi dalam pendisiplinan di kelas (Ef4). Benets dan Vergauwen (2004:156-164) yang membandingkan orientasi nilai yang dimiliki guru-guru sekolah dasar dengan sekolah menengah menemukan bahwa guru sekolah dasar lebih menempatkan prioritas tinggi dalam penguasaan disiplin. Bila memang guru madrasah cenderung berorientasi pada penguasaan disiplin pada siswa, maka yang membedakan tinggi rendahnya kecenderungan tersebut adalah tingkat religiusitasnya. Mereka yang lebih berorientasi keagamaan akan lebih berupaya dalam mendisiplinkan siswa. Sebagai Muslim yang religius, guru madrasah menyadari betul bahwa pelaksanaan ajaran-ajaran dan ibadah dalam agama Islam menuntut dasar-dasar kedisiplinan yang baik. Dengan demikian, dapat dikatakan bahwa faktor religiusitas memengaruhi efikasi guru dalam pendisiplinan siswa di kelas.

Efikasi pelibatan masyarakat guru umumnya berada pada level sedang (78,78\%). Sebagaimana pelibatan orangtua wali murid, pelibatan masyarakat tidak sebatas pada pendanaan, tetapi meliputi berbagai kemungkinan kerja sama dan akses. Mengingat efikasi pelibatan masyarakat guru madrasah dalam penelitian masih tergolong sedang, maka dapat dipahami mengapa madrasah yang pada dasarnya berakar dari idealisme masyarakat berangsur-angsur terlepas dari campur tangan masyarakat itu sendiri. Bila dilihat dari sisi guru, berkurangnya partisipasi ini dipengaruhi kurangnya upaya madrasah khususnya guru dalam menjalin berbagai kerjasama dengan masyarakat. Pada sisi lain, pemerintah mulai ikut andil dalam pemberdayaan madrasah. Ada beberapa prediktor yang diketahui berkorelasi dengan efikasi dalam pelibatan masyarakat yaitu lama menjadi guru dan status sosial ekonomi.

Sekolah merupakan lembaga sosial yang tidak bisa dipisahkan dengan masyarakat. Menurut Mulyasa (2002:19-31), tujuan hubungan antara sekolah dan masyarakat adalah memelihara kelangsungan hidup sekolah, meningkatkan mutu pendidikan di sekolah, memperlancar kegiatan belajar dan mengajar, dan membantu pendanaan serta dukungan program sekolah.

Efikasi total tidak dapat diprediksi dari sembilan variabel, sementara itu beberapa dimensi efikasi dapat diprediksi dengan 
baik oleh beberapa faktor. Hal ini mengindikasikan bahwa prediktor yang diuji dalam penelitian ini tidak mampu meramalkan efek terhadap efikasi guru secara total. Walaupun demikian, beberapa dimensi efikasi dapat diprediksi oleh beberapa prediktor sekaligus. Efikasi pengambilan keputusan di sekolah dapat diprediksi bersamasama oleh persepsi kompetensi, etnisitas, dan religiusitas $(\mathrm{R}=0,29 ; \mathrm{R}$ square $=0,087 ; \mathrm{F}=4,045 ; \mathrm{p}=0,009)$. Hal ini menunjukkan bahwa $8,7 \%$ efikasi pengambilan keputusan di sekolah disumbang oleh ketiga faktor tersebut. Selain itu, sembilan prediktor yaitu religiusitas, etnisitas, persepsi kompetensi, status sosial ekonomi, persepsi kesejahteraan, persepsi sertifikasi, lama mengajar, ipk, dan umur bersama-sama juga memprediksi efikasi pengambilan keputusan di sekolah $(\mathrm{R}=0,362 ; \mathrm{R}$ square $=0,0131 ; \mathrm{F}=2,2041 ; \mathrm{p}=0,04)$.

Secara bersama-sama status sosial ekonomi dan lama mengajar ditemukan berefek terhadap efikasi pelibatan masyarakat atau $\mathrm{Ef6}(\mathrm{R}=0,25 ; \mathrm{R}$ square $=0,063 ; \mathrm{F}=4,35 ; \mathrm{p}=0,015)$. Sebanyak 6,3\% efikasi pelibatan masyarakat disumbang oleh dua faktor tersebut.

Hasil efikasi intruksional (Ef3) tergolong sedang artinya para responden menganggap upayanya dalam aspek pengajaran belum optimal atau dengan kata lain sebagian besar guru madrasah masih merasa kurang yakin dengan kemampuan dan ketrampilan mengajar. Data lain juga mengindikasikan hal yang serupa yaitu pertama, data persepsi guru dalam kompetensi mengajar. Persentase terbesar adalah 63,65\% yang merasa cukup kompeten. Kedua, data lama mengajar menunjukkan bahwa persentase terbesar 41,66\% adalah guru masih sangat muda yakni mereka yang baru 1 sampai 6 tahun menjadi guru. Ketiga, data usia menunjukkan bahwa persentase terbanyak kedua, berumur dewasa awal 20-33 tahun. Penilaian diri atas kompetensi, pengalaman menjadi guru yang masih pemula, dan usia yang berada pada tahap dewasa awal menjadi faktor-faktor yang memengaruhi efikasi guru madrasah dalam aspek instruksional yang berada pada taraf sedang.

Hubungan sekolah dengan orangtua dijalin berdasar adanya kesamaan tanggung jawab dan tujuan. Kesamaan tanggung jawab artinya kedua pihak sama-sama memiliki kewajiban untuk mendidik anak dalam lingkungan keluarga dan sekolah. Menurut Mulyasa (2002:19-31), hubungan kerja sama antara sekolah dengan orangtua 
murid bertujuan untuk saling membantu, memberikan bantuan keuangan serta barang, mencegah perbuatan yang kurang baik, dan merencanakan yang terbaik untuk anak. Dalam Park dan Kim (2006:421-444), dinyatakan bahwa orang tua memiliki pengaruh sangat kuat dalam pencapaian prestasi anak. Apabila guru dapat menggunakan kekuatan ini, maka diharapkan siswa madrasah akan lebih berprestasi.

Dalam indikator efikasi pelibatan orangtua siswa, guru mayoritas menempati posisi sedang $(65,9 \%)$. Temuan ini menunjukkan bahwa para guru madrasah belum maksimal berupaya dalam menstimulasi keterlibatan orangtua murid. Madrasah sebagaimana sekolah lain memiliki suatu dewan yang mewakili posisi wali murid yang dikenal dengan Komite Madrasah. Pelibatan yang dimaksud di sini tidak terbatas membentuk komite, tetapi juga memberdayakan serta bekerjasama untuk meningkatkan partisipasi wali murid dalam aspek-aspek pembelajaran di madrasah.

Efikasi pelibatan orangtua murid berdasar hasil analisis uji komparasi diketahui bahwa kelompok tua lebih efikasius dibanding kelompok muda. Kelompok tua adalah guru yang berusia 40 tahun ke atas, sedang kelompok muda adalah guru berusia di bawah 40 tahun. Bila mengacu pada hasil penelitian Van Petegem et al. (2005:34-43) maka lamanya pengalaman menjadi guru memengaruhi penghayatan diri si guru terhadap kesejahteraan psikologisnya. Sementara itu, kesejahteraan guru meliputi kondisi emosional positif dan harmoni antara konteks sekolah dengan pribadi guru, maka amat logis jika lama mengajar merupakan pembeda signifikan dalam urusan pelibatan orangtua murid dalam kegiatan sekolah. Semakin lamanya mengajar juga menjadi bekal pengalaman bagaimana membangun hubungan positif dengan orangtua agar dapat bekerja sama dalam penanganan siswa. Keluwesan bergaul juga amat dipengaruhi oleh pengalaman dan kedewasaan usia guru.

Penelitian ini menjumpai bahwa para responden memiliki efikasi yang tinggi pada aspek penciptaan iklim positif di sekolah (Ef7). Hal ini sesuai dengan konsep Bronfenbrenner (1979:132163) yang menyatakan bahwa sekolah termasuk juga kelas adalah sebuah mikrosistem yang ditandai oleh beberapa relasi interpersonal. 
Relasi interpersonal antara guru dengan siswa lebih ditentukan oleh kecenderungan guru dibandingkan faktor kemauan murid. Ada guru yang lebih menyukai lingkungan disiplin untuk belajar, sementara yang lain lebih menyenangi atmosfer kelas yang menyenangkan. Bagi guru yang memilih relasi interpersonal dengan dasar kepercayaan (trust) siswa pada guru, akan condong untuk menampilkan diri sebagai sosok yang suka menolong dan penyayang. Dalam situasi kelas yang hangat tersebut, siswa dianggap lebih nyaman dan aman untuk mengekspresikan pikiran. Agar tercipta suasana kondusif untuk belajar, guru membutuhkan kenyamanan di tempat kerjanya baik di sekolah maupun di ruang kelas. Alasan-alasan inilah yang mendorong guru merasa lebih efikasius dalam penciptaan iklim positif di sekolah.

\section{Kesimpulan}

Pertama, dari 132 responden guru madrasah ibtidaiyah, efikasi total paling banyak berada pada level sedang (39,4\%) sampai tinggi (32,6\%). Namun masih ada 16,7\% guru MI yang berefikasi rendah dan 2,2\% yang sangat rendah, sedang sisanya 9,1\% berefikasi sangat tinggi.

Kedua, tingkat efikasi dilihat dari masing-masing dimensi dapat dikelompokkan menjadi dua yaitu kelompok efikasi tinggi meliputi efikasi pengambilan keputusan, pengadaan sumber daya, pendisiplinan, dan penciptaan iklim positif di sekolah. Kelompok kedua, level efikasi sedang meliputi efikasi dalam instruksional, pelibatan orangtua, dan pelibatan masyarakat.

Hal ini mengindikasikan bahwa profil efikasi guru madrasah cukup mengesankan. Temuan studi ini, memunculkan sinyalemen positif di mana persepsi negatif yang menyatakan bahwa guru madrasah cenderung fatalis tidak sepenuhnya benar. Persoalan lebih lanjut adalah, apakah efikasi guru ini mampu benar-benar digunakan dapat diekspresikan guru dengan baik dan berdampak pada outcome siswa. Untuk itu perlu dilakukan kajian mengenai dampak efikasi guru madrasah terhadap berbagai keberhasilan siswa.

Ketiga, berdasarkan analisis statistik, tidak diketemukan prediktor yang signifikan terhadap tingkat efikasi guru total. 
Keempat, diketemukan prediktor berkorelasi positif dengan beberapa dimensi efikasi yaitu: a) Efikasi pengambilan keputusan dipengaruhi oleh sembilan prediktor secara bersama-sama meliputi religiusitas, etnisitas, kompetensi, lama mengajar, status sosial ekonomi, laporan kesejahteraan guru, efek sertifikasi pada kinerja, umur, dan indeks prestasi kumulatif. Efikasi pengambilan keputusan juga memiliki koefisien determinasi lebih tinggi ketika hanya tiga prediktor dimasukkan yaitu religiusitas, etnisitas, dan kompetensi. Ini artinya tiga prediktor tersebut secara bersama-sama lebih memprediksi efikasi pengambilan keputusan. b) Efikasi pengadaan sumber daya dapat diprediksi dari status sosial ekonomi. c) Efikasi pendisiplinan kelas dapat diprediksi dari religiusitas. d) Efikasi pelibatan masyarakat dapat diprediksi dari lama guru mengajar. Selain itu, status sosial ekonomi bersama-sama dengan lama guru mengajar memprediksi efikasi pelibatan masyarakat secara signifikan.

Religiusitas, etnisitas, persepsi kompetensi, status sosial ekonomi, dan lama mengajar merupakan prediktor yang perlu dicuatkan untuk mempertimbangkan intervensi yang dapat diprogramkan untuk meningkatkan efikasi guru madrasah.

\section{Daftar Pustaka}

Bandura, A. 1986. Social Foundations of Thought and Action; a Social Cognitive Theory. Englewood Cliffs, New Jersey: Prentice-Hall.

Bandura, A. 1997. Self-Efficacy; The Exercise of Control. New York: W.H. Freeman and Company.

Benets, D. dan Vergauwen, L. 2004. Value Orientation of Elementary and Secondary Physical Education Teachers in Flanders. Research Quarterly for Exercise and Sport, 75, 156-164.

Biro Kepegawaian Sekretaris Jenderal Departemen Agama Republik Indonesia. 2004. Basic Kompetensi Guru; Modul Orientasi Pembekalan Calon PNS. Jakarta: Proyek Pembibitan Calon Tenaga Kependidikan.

Bronfenbrenner, U. 1979. The Ecology of Human Development; Experiments by Nature and Design. Cambridge, MA : Harvard 
University Press.

Cakiraglu, J., Cakiroglu, E., \& Boone, W.J. 2005. Pre-service Teacher Self-Efficacy Beliefs Regarding Science Teaching: A Comparison of Pre-Service Teachers in Turkey and the USA. Science Educator, 14, 31-40.

Campbell, J. 1996. A Comparison of Teacher Efficacy for Pre and in-Service Teacher in Scotland and America. Education, 117, 2-11.

Chang, T-S., McKeachie, W., \& Lin, Y-G. 2010. Faculty Perceptions of Teaching Support and teaching Efficacy in Taiwan. Education, 59, 207-230.

Cheung, H.Y. 2008. Teacher Efficacy: A Comparative Study of Hong Kong and Shanghai Primary in-Service Teachers. The Australian Educational Reseacher, 35, 103-123.

Field, A. 2000. Discovering Statistic Using SPSS for Windows: Advances Techniques for the Beginner. London: Thousand Oaks.

Ghazali, I. 2001. Aplikasi Analisis Multivariate dengan Program SPSS. Semarang: Badan Penerbit Universitas Diponegoro.

Houkamau, C.A., \& Sibley, C.G. 2010. Maori Cultural Efficacy and Subjective Wellbeing: A Psychological Model and Research Agenda. Soc Indic Res, DOI 10. 1007/s11205-010-9705-5, 121.

Huang, X., \& Liu, M. 2007. An Analysis of the Relationships between Teacher Efficacy, Teacher Self-Esteem, and Orientations to Seeking Help. Social Behavior and Personality, 35, 707-716.

Issao, S. dan Michael, W.B. 1981. Handbook in Research and Evaluation. San Diego, Ca: EDITS Publishers.

Jennetts, H.K., Harris, S.L., \& Mesibor, G.B. 2003. Commitment to Philosophy, Teacher Efficacy, and Burnout among Teachers of children with Autism. Journal of Autism and Developmental Disorder, 33, 583-593.

Kusnan. 2000. Kemampuan Manajerial Kepala Madrasah dan Implikasinya terhadap Kinerja Guru. Iqra,3,1-13.

Lee, M-H., \& Tsai, C-C. 2010. Exploring Teacher's Perceived SelfEfficacy and technological Paedagogical Content knowledge 
with Respect to Educational Use of the World Wide Web. Instr Sci, 38, 1-21, DOI 10. 1007/s11251-008-9075-4.

Milson, A.J. \& Mehlig, L.M. 2002. Elementary School Teachers Sense of Efficacy for Character Education. The Journal of Educational Research, 96, 47-54.

Mulyasa, E. 2002. Manajemen Berbasis Sekolah; Konsep, Strategi, dan Implementasi. Bandung: Remaja Rosdakarya.

Nunn, G.D., \& Jantz, P.B. 2009. Factors within Response to Intervention Implementation Training Associated with Teacher Efficacy Beliefs. Education, 129, 599-607.

Park, Y-S., \& Kim, U. (2006). Family, Parent-child Relationship, and Academic Achievement in Korea: Indigenous, Cultural, and Psychological Analysis. In Kim,U., Yang,K-S., Hwang,K.K. (Eds.); Indigenous and Cultural Psychology; Understanding People in Context. New York: Springer.

Rosyada, D. 2004. Paradigma Pendidikan Demokratis: Sebuah Model Pelibatan Masyarakat dalam Penyelenggaraan Pendidikan. Jakarta: Kencana.

Ross, J.A., \& Gray, P. 2006. School Leadership and Student Achievement: the Mediating Effects of Teacher Beliefs. Canadian Journal of Education, 29, 798-920.

Slavin, R.E. 2012. Educational Psychology: Theory and Practicetenth edition. Boston: Pearson.

Tschannen-Moran, M., Hoy, A.W., and Hoy, W.K. 1998. Teacher Efficacy: Its Meaning and Measure. Review of Educational Research, 68, 202-248.

Van Petegem, Creemers, B.P.M., Rossell,Y., dan Aelterman, A. 2005. Relationships between Teacher Characteristics, Interpersonal Teacher Behavior, and Teacher Wellbeing. The Journal of Classroom Interaction, 40, 34-43.

Wahyuningtyas, D., Prihastiwi, W.J., dan Nastiti, D. 2000. Perbedaan Motivasi Belajar pada Bidang Matematika Ditinjau dari Intensitas Interaksi Guru-siswa di SMU Semen Gresik. Arketipe, 1, 41-47.

Wertheim, C. dan Leyser, Y. 2002. Efficacy Beliefs, Background Variables, and Differentiated Instruction of Israeli Prospective Teacher. The Journal of Educational Research, 96, 54-63. 